\title{
A new species of Telmatoscopus Eaton (Diptera, Psychodidae) from Brazil
}

\author{
Freddy Bravo ${ }^{1,2}$; Isys Souza ${ }^{1}$ \\ ${ }^{1}$ Departamento de Ciências Biológicas, Universidade Estadual de Feira de Santana - UEFS, \\ Av. Universitária s/n, CEP 44031-460, Feira de Santana, BA, Brazil \\ ${ }^{2}$ Corresponding author: Freddy Bravo, e-mail: freddyllbravo@yahoo.com.br
}

Bravo, F.; Souza, I. A new species of Telmatoscopus Eaton(Diptera, Psychodidae) from Brazil. Biota Neotrop., vol. 8, no. 1, Jan./Mar. 2008. Available from: <http://www.biotaneotropica.org.br/v8n1/en/abstract?article+bn0 $1408012008>$.

Abstract: A new Brazilian species of Telmatoscopus Eaton (Diptera, Psychodidae) is described and illustrated. A key to males of Neotropical species of Telmatoscopus is provided.

Keywords: Diptera, Psychodidae, Amazon, new species, Brazil.

Bravo, F.; Souza, I. Espécie nova de Telmatoscopus Eaton (Diptera, Psychodidae) do Brasil. Biota Neotrop., vol. 8, no. 1, jan./mar. 2008. Disponível em: <http://www.biotaneotropica.org.br/v8n1/pt/abstract?article+bn01 408012008>.

Resumo: Neste trabalho é descrita e ilustrada uma espécie nova de Telmatoscopus Eaton (Diptera, Psychodidae) do Brasil. É fornecida uma chave para os machos das espécies Neotropicais de Telmatoscopus.

Palavras-chave: Diptera, Psychodidae, Amazônia, espécie nova, Brasil. 


\section{Introduction}

The genus Telmatoscopus Eaton has worldwide distribution and comprises, according to The Diptera Site (Thomson 2007), approximately 109 species. The genus Telmatoscopus is poorly represented in the Neotropical region, having only 6 described species (Duckhouse 1968, Wagner 1993, 2000, Quate 1996). Only one species is known from Brazil, Telmatoscopus calcaratus Duckhouse, from Nova Teutônia, Santa Catarina State, in southern Brazil (Duckhouse 1968), and only from female specimens. A new species of Tematoscopus from the Brazilian Amazon region is described here.

\section{Material and Methods}

The specimens studied were treated with $10 \% \mathrm{KOH}$, dehydrated and mounted in Canada balsam. Morphological terminology follows that of McAlpine (1981). The specific morphological terminology for Psychodidae follows that of Duckhouse (1990) and Bravo (2006, 2007). The specimens were deposited in the Coleção de Invertebrados do Instituto Nacional de Pesquisas da Amazônia (INPA) and Coleção Entomológica Prof. Johann Becker do Museu de Zoologia da Universidade Estadual de Feira de Santana, Feira de Santana, Bahia, Brazil (MZUEFS).

\section{Results}

\section{Telmatoscopus brevicolis Bravo \& Souza, sp. nov.}

(Figures 1-10)

\section{Diagnosis}

Hair patch of frons undivided, with a single row of scars extending to upper eye margin nearly to suture; Sc enlarged apically, $\mathrm{R}_{2}$ enlarged at base, $\mathrm{CuA}$ enlarged near center; hypandrium U-shaped, thickened medially; aedeagus symmetrical, subcircular; gonocoxal apodemes extended posteriorly, canal-like, longer than the length of aedeagus.

\section{Description}

Male: Eye bridge with 4 facet rows, separated by 1 facet diameter. Interocular suture present, complete, V-shaped (Figure 1). Hair patch of frons undivided, with single row of scars extending to upper eye margin nearly to suture (Figure 1). Lacinia blade-like (Figure 2). Labela with apical bristles (Figure 2). Antenna: scape cylindrical 1.4x length of pedicel (Figure 3); pedicel spherical (Figure 3); 14 flagellomeres present; flagellomeres nodiform and asymmetrical (Figures 3, 4); $1^{\text {st }}$ flagellomere with short internode (Figure 3); following internodes longer than first (Figures 3,4); 14 ${ }^{\text {th }}$ with long apiculus (Figure 4); pair of ascoids curled (Figure 3); sensory organ of flagellomeres absent. Palpus formula = 1.0:1.2:1.1:1.6 (Figure 5); last palpomere striated (Figure 5). Wing (Figure 6): Sc enlarged apically, $\mathrm{R}_{2}$ enlarged at base, $\mathrm{M}_{3}$ and $\mathrm{CuA}$ enlarged near center; one paratype specimen without enlargement in $\mathrm{M}_{3}$; medial fork and radial fork almost at the same level; $\mathrm{R}_{3}$ fused to $\mathrm{R}_{2}$, except in two paratype specimens with $\mathrm{R}_{3}$ not fused to $\mathrm{R}_{2} ; \mathrm{R}_{5}$ ending beyond rounded apex of the wing; $\mathrm{CuA}$ ending at the same level as the medial fork. Male terminalia: epandrium rectangular, with bristle patches in lateral posterior areas (Figures 7, 8); presence of two foramina (Figure 8). Cercus pilose, long, 1.5x length of gonostylus, slightly curved, with 5 apical tenacula (Figure 7). Tergite 10 with small bristles at apex; apex subtriangular (Figure 9). Hypandrium U-shaped, thickened medially (Figure 9). Gonocoxite pilose, same length as gonostyle (Figures 7,9), with three long basal bristles at its base on the inner side (Figure 9). Gonostylus pilose, pointed at apex (Figures 7, 9). Gonocoxal apo-
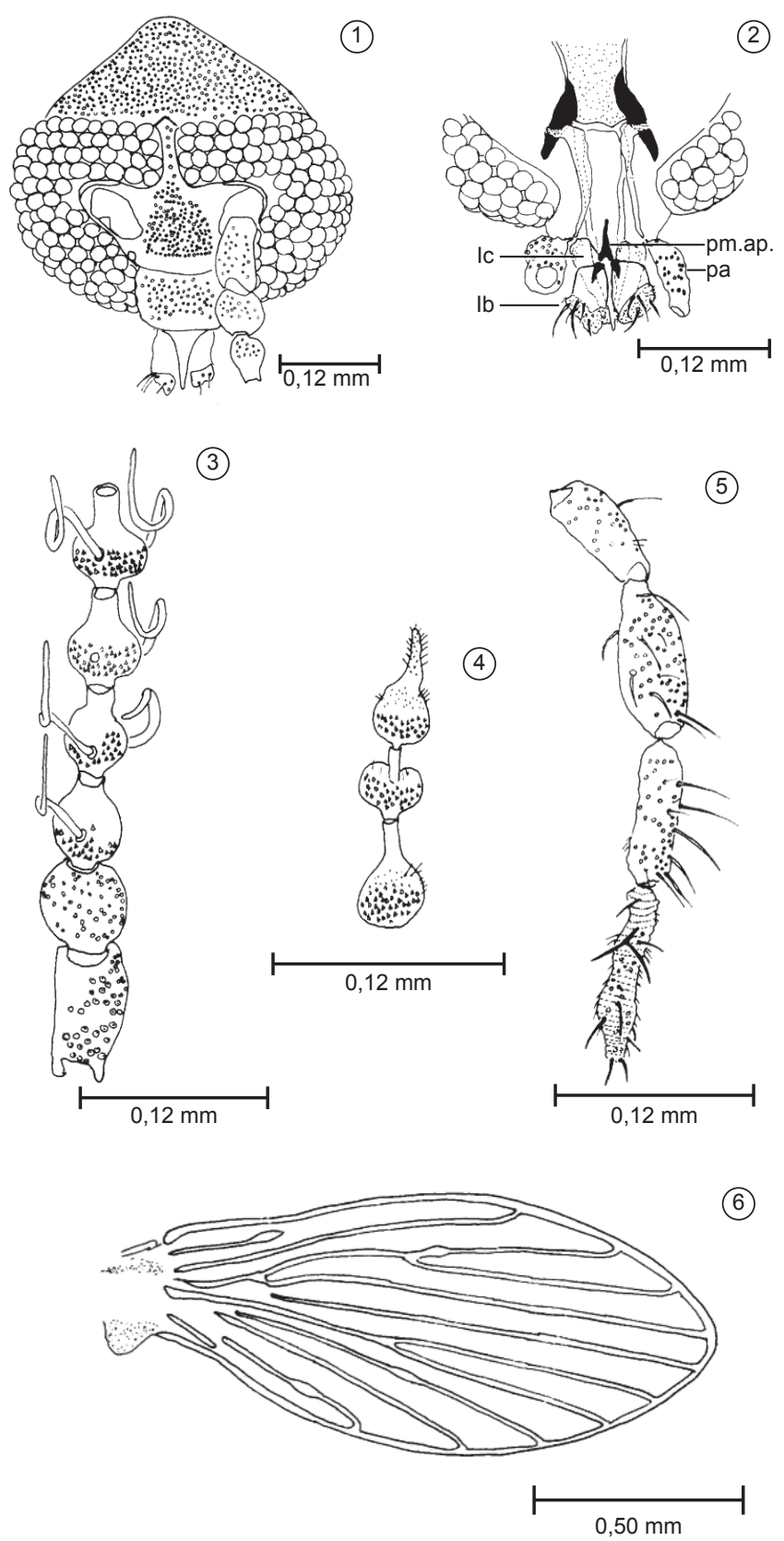

Figures 1-6. Telmatoscopus brevicolis Bravo \& Souza, sp. nov. Male. 1) Head. 2) Head, posterior view. 3) Antenna: scape, pedicel and basal flagellomeres. 4) Antenna, flagelomeres 12-14. 5) Palpus. and 6) Wing. (cd = cardo; lb = labella; $\mathrm{lc}=$ lacinia; $\mathrm{pa}=$ palpus; $\mathrm{pm} . \mathrm{ap} .=$ premental apodeme; $\mathrm{st}=$ stipes $)$

Figuras 1-6. Telmatoscopus brevicolis Bravo \& Souza, sp. nov. Macho. 1) Cabeça. 2) Cabeça, vista posterior. 3) Antena: escapo, pedicelo e flagelômeros basais. 4) Antena, flagelômeros 12-14. 5) Palpo. 6) Asa. $\mathrm{cd}=$ cardo $; \mathrm{lb}=$ labela $; \mathrm{lc}=$ lacinia $; \mathrm{pa}=$ palpo maxilar; pm.ap. = apódema pré-mental; st $=$ estipes.

demes joined on midline and forming a gonocoxal bridge (Figure 9), extended posteriorly to midline, canal-like, longer than length of aedeagus, attached at base of aedeagus (Figures 7, 9, 10). Sternite 10 micropilose, hemicircular. (Figures 7,9). Aedeagus symmetrical, subcircular (Figures 9, 10); membranous area present above aedeagus (Figure 7), triangular dorsally (Figures 9). Aedeagal apodeme 0.8x length of aedeagus (Figures 9, 10). Parameres absent.

Type Material: BRAZIL, Pará, Santarém, Est. do Aeroporto Km 13, Comunidade Santa Maria, Chácara N. Sra. Nazaré (Mata 

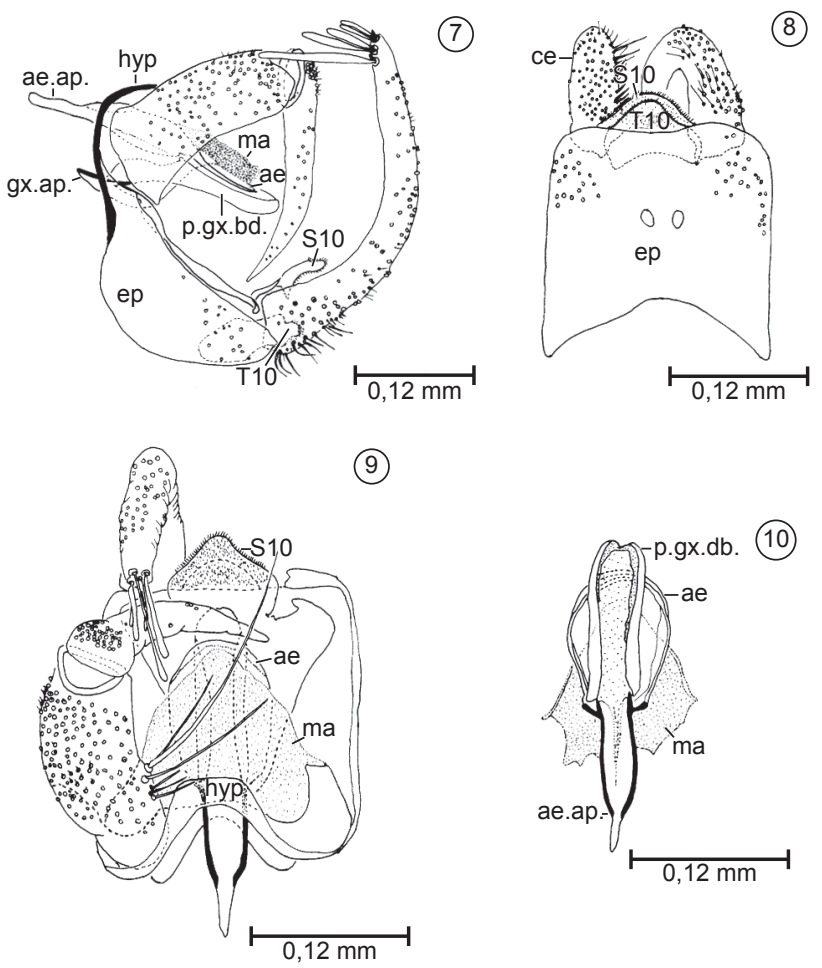

Figures 7-10. Telmatoscopus brevicolis Bravo \& Souza, sp. nov. Male terminalia. 7) Lateral. 8) Ventral. 9) dorsal. and 10) Aedeagus. (ae = aedeagus; ae.ap. = aedeagal apodeme; ce = cercus; ep = epandrium; hyp = hypandrium; gx.ap. = gonocoxal apodeme; $\mathrm{ma}=$ membranous área; p.gx.bd. = posterior prolongation of gonogoxal bridge; $\mathrm{S} 10=$ sternite $10 ; \mathrm{T} 10=$ tergite 10 ).

Figuras 7-10. Telmatoscopus brevicolis Bravo \& Souza, sp. nov. Terminália masculina. 7) Vista lateral. 8) Vista ventral. 9) Vista dorsal. e 10) Edeago. (ae = edeago; ae.ap. = apódema edeagal; ep = epândrio; $c$ e = cerco; hyp = hipândrio; gx.ap. = apódema gonocoxal; $\mathrm{ma}=$ área membranosa; .gx.bd. = prolongamento posterior da ponte gonocoxal; $\mathrm{S} 10=$ esternito $10 ; \mathrm{T} 10=$ tergito 10 )

Alterada), 25.XI.1998, RF/RDN/FLS col., holotype male (INPA); 1 paratype male, same locality, date, and collectors as holotype (INPA); 7 paratype males, same locality and collectors, 27.XI.1998 (INPA, MZUEFS).

Etymology: "brevis" Latin, short; “colis", Latin, penis; referring to the short aedeagus in comparison to the posterior expansion of the gonocoxal bridge.

\section{Comments}

The genus Telmatoscopus was defined by Quate (1996). All of the characters mentioned by Quate (1996) to distinguish Telmatoscopus are recognized in the new species Telmatoscopus brevicolis.

The Brazilian species Telmatoscopus calcaratus, known only from females, differs from other Neotropical species of the genus in demonstrating a fusion of the $13^{\text {th }}$ and $14^{\text {th }}$ flagellomeres (Duckhouse 1968), a characteristic not observed in other Telmatoscopus species from this biogeographical region. It is important to note that the enlargement of some veins, as observed in the new species T. brevicolis, was also observed in the three Costa Rican species: T. clavatus Quate, T. congruus Quate, and T. mergacolis Quate (see descriptions in Quate 1996). The difference between these species resides in the enlargement of veins $\mathrm{Sc}, \mathrm{R}_{2}$, and $\mathrm{CuA}$ in the new species (in some specimens, $\mathrm{R}_{3}$ also demonstrates enlargement), while only the $\mathrm{Sc}$ and $\mathrm{CuA}$ veins are enlarged in Costa Rican species.

Duckhouse (1968) recorded another species of Telmatoscopus from Brazil (Nova Teutônia, Santa Catarina State): T. furcatus
(Kincaid). This species was first described from the United States, and Duckhouse (1968) presumes that $T$. furcatus was introduced into Brazil. The generic status of this species is controversial. The Diptera Site (Thomson 2007) recorded this species as T. furcatus. Quate (1996) transferred T. furcatus to the genus Duckhousiella Vaillant, because of its similarity to $D$. ustulatus (Walker), and he presented a new record of this species from Costa Rica.

Duckhouse (1978) synonymized Duckhousiella with Paramormia Enderlein. This synonymy was accepted by The Diptera Site (Thompson 2007) and by the Fauna Europaea Web Service (2004). Ježek (2004a, b), on the other hand, recognizes Duckhousiella as one of the three subgenera of the genus Paramormia. The Brazilian species is recorded as Paramormia furcata in the ZooBank (2007). Ježek (2004a, b) accepted the presence of one species of Paramormia from the Nearctic and Neotropical regions. The ascoids of males of P. furcata are typical of the genus Paramormia and, as Quate (1996) noted, the male terminalia of $P$. furcata is similar to male terminalia of P. ustulata (Walker), a Palaearctic species. Until new taxonomic studies can be undertaken, the name $P$. furcata is accepted in this paper.

\section{Key to males of Neotropical Telmatoscopus}

1. Cercus with $4-5$ tenacula .......................................................... 2

- Cercus with more than 5 tenacula 5

2. Sc enlarged apically and $\mathrm{CuA}$ enlarged near center ........ 3

- Sc and CuA not enlarged, uniformly wide ..T. caribicus Wagner (Saint Vincent, Caribbean)

3. Gonocoxal apodemes extended posteriorly to midline with cluster of 4 non-deciduous spines on metabasal angle and additional 2 further distad... T. clavatus (Costa Rica)

- Gonocoxal apodemes without posterior extension or, if extended posteriorly, never with spines ................................................. 4

4. $\mathrm{R}_{2}$ enlarged at base; eye bridge separated by 1 facet diameter .T. brevicolis sp. nov. (Brazil, Amazonian) - $\mathrm{R}_{2}$ not enlarged; eye bridge separated by 2 facet diameters .... .T. mergacolis (Costa Rica)

5. Cercus with 15 tenacula; eye bridge separated by 1.5 facet diameters, aedeagal apodeme narrow in dorsal view T. congruus Costa Rica

- Cercus with 7-9 tenacula; eye bridge separated by 3.5 facet diameters, aedeagal apodeme wide in dorsal view ...... T. thompsoni Wagner Dominican Republic

\section{Acknowledgments}

The authors would like to thank to Dr. Augusto Loureiro Henriques from INPA who loaned the specimens. FB received financial support from CNPq (470754/2003-6) and FAPESB (PPP) and has a research grant from CNPq (306426/2006-4).

\section{References}

BRAVO, F. 2006. The taxonomy of Neotropical Brunettiina (Diptera, Psychodidae, Psychodinae, Mormiini) with descriptions of ten new species from Brazil and comments on the generic classification of this subtribe. Zootaxa. (1134):1-28.

BRAVO, F., 2007. A new species of Australopericoma Vaillant (Diptera, Psychodidae) from Brazilian semi-arid region. Biota Neotrop. 7(2): http:// www.biotaneotropica.org.br/v7n2/pt/fullpaper?bn04507022007+en 
DUCKHOUSE, D.A. 1968. Psychodidae (Diptera, Nematocera) collected by Mr. Plaumann in Southern Brazil. Proc. R. Entomol. Soc. London, Ser. B. 37:29-48.

DUCKHOUSE, D.A. 1968. Non-phlebotomine Psychodidae (Diptera,Nematocera) of southern Africa. II. Subfamily Psychodinae: Neoarisemus and the brunettoid and telmatoscopoid genera. Ann. Natal Mus. 23: 305-359.

DUCKHOUSE, D.A. 1990. The Australasian genera of Pericomoid Psychodidae (Diptera) and the status of related Enderlein genera in the Neotropics. Invertebr. Taxon. 3:721-746.

FAUNA EUROPAEA WEB SERVICE. 2004. Fauna Europaea version 1.1, http://www.faunaeur.org. (last access in 19/09/2007).

JEŽEK, J. 2004a. New taxa of non-biting moth flies (Diptera, Psychodidae, Psychodinae, Paramormiini) from Madagascar. Acta Facultatis Ecologiae. 12:57-68 (Supl. 1).

JEŽEK, J. 2004b. New species of moth flies (Diptera, Psychodidae, Psychodinae) from Laos, Malaysia and Vietnam. Folia Fac. Sci. Nat. Univ. Masaryk. Brun., Biol., 109:129-140.
McALPINE, J.F. 1981. Morphology and terminology: adults. In Manual of Neartic Diptera (J.F. Mcalpine, B.V. Peterson, G.E. Shewell, H.J. teskey, J.R. Vockeroth \& D.M. Wood, eds.). Research Branch, Agriculture Canada v. 1, Monograph n ${ }^{\circ}$ 27, Ottawa, p.9-63.

QUATE, L.W. 1996. Preliminary taxonomy of Costa Rican Psychodidae (Diptera), exclusive of Phlebotominae. Rev. Biol. Trop. 44:1-81. (Supplement 1).

THOMPSON, F.C. (editor). 2007. Biosystematic Database of World Diptera: http://www.diptera.org/biosys.htm. (last access in 19/09/2007).

WAGNER, R. 1993. On a collection of Psychodidae ( Diptera) by Dr. L. Botosaneanu from some caribbean islands. Aquatic Insects. 15:109-127.

WAGNER, R. 2000. Psychodidae from the Dominican republic: records and descriptions of new species (Insecta: Diptera). J. Kansas Entomol. Soc. 72:233-245

ZOOBANK. 2007. Zoobank. http://www.zoobank.org. (last access 19/09/2007).

Data Received 14/10/07 Revised 12/01/08

Published 21/01/08 